\title{
UPAYA PENINGKATAN PROFITABILITAS USAHA
}

\author{
Evy Ratnasari
}

\author{
Fakultas Ilmu Sosial dan Ilmu Politik Universitas Kapuas Sintang \\ Jln. Oevang Oeray Nomor 92 Baning Kota Sintang \\ Email: evyratnasari erando@gmail.com
}

\begin{abstract}
Abstrak: Perusahaan sebagai salah satu bentuk organisasi pada umumnya memiliki tujuan tertentu yangingin dicapai dalam usaha untuk memenuhi kepentingan para stake holder. Adapun tujuan perusahaanantara lain untuk memperoleh keuntungan(profit),meningkatkan nilai perusahaandan untukmemuaskan kebutuhan masyarakat. Tercapainya tujuan tersebutditentukan oleh kinerja yang nantinyadapat dijadikan sebagai dasar pengambilan keputusan baik pihak internal maupun eksternal.

Memaksimalisasi nilai perusahaan, tujuan ini merupakan sasaran jangka panjang, yaitu bagaimanamemperbaiki kinerja perusahaan sehingga kinerja yangbaik itu mendorong naiknya harga saham di bursa danpada akhirnya menaikkan nilai perusahaan. Tidak dapatdiingkari bahwa tujuan menghasilkan laba adalah tujuan mendasar semua perusahaan.
\end{abstract}

Kata Kunci : Upaya Peningkatan, Profitabilitas Usaha

Profitabilitas merupakankemampuan suatu perusahaan untuk mendapatkan laba(keuntungan) dalam suatu periode tertentu. Pengertian yang sama disampaikan oleh Husnan(2001:112) bahwa "Profitabilitas adalah kemampuan suatu perusahaan dalam menghasilkankeuntungan (profit) pada tingkat penjualan, aset, dan modal saham tertentu". SedangkanMenurutMichelle \& Megawati (2005:201) "Profitabilitas merupakan kemampuan perusahaan menghasilkanlaba (profit) yang akan menjadi dasar pembagian dividen perusahaan". Prolitabilitas menggambarkan kemampuan badan usaha untuk menghasilkanlaba dengan menggunakan seluruh modal yang dimiliki. Profitabilitasperusahaan merupakan salah satu dasar penilaian kondisi suatu perusahaan, untukitu dibutuhkan suatu alat analisis untuk bisa menilainya. Alat analisis yang dimaksud adalah rasiorasiokeuangan. Ratio profitabilitas mengukur efektifitas manajemen berdasarkan hasil pengembalian yangdiperoleh dari penjualan dan investasi.

Profitabilitas juga mempunyai arti penting dalam usaha mempertahankan kelangsunganhidupnya dalam jangka panjang, karena profitabilitas menunjukkan apakah badan usaha tersebutmempunyai prospek yang baik di masa yang akan datang. Dengan demikian setiap badan usahaakan selalu berusaha meningkatkan profitabilitasnya, karena semakin tinggi tingkat profitabilitassuatu badan usaha maka kelangsungan hidup badan usaha tersebut akan lebih terjamin. Profitabilitas keuangan perusahaan sudah tentu merupakan kinerja perusahaan yangditinjau dari kondisi keuangan perusahaan. Profitabilitas keuangan perusahaan tercermin darilaporan keuangannya, oleh sebab itu untuk mengukur profitabilitas keuangan perusahaandiperlukan analisis terhadap laporan keuangannya. Secara umum profitabilitasmerupakan pengukuran dari keseluruhan produktivitas dan kinerja perusahaan yang padaakhirnya akan menunjukkan efisiensi dan produktivitas perusahaan tersebut.

Prastowo (2008:251) menyatakan bahwa "informasi kinerja perusahaan, terutamaprofitabilitas diperlukan untuk menilai perubahan potensial sumber daya ekonomi yangmungkin dikendalikan di masa depan, sehingga dapat memprediksi kapasitas perusahaan dalammenghasilkan kas (dan setara kas) serta untuk merumuskan efektifitas perusahaan dalammemanfaatkan tambahan sumber daya". Profitabilitas merupakan salah satu pengukuran bagi kinerja suatu perusahaan, profitabilitas suatu perusahaan menunjukan kemampuan suatu perusahaan dalam menghasilkan laba selama pereode tertentu pada tingkat penjualan, asset dan modal saham tertentu. Profitabilitas suatu perusahaan dapat dinilai melalui berbagai cara tergantung pada laba dan aktiva atau modal yang akan diperbandingkan satu dengan lainya.

Return on equity atau profitabilitas adalah Suatu pengukuran dari penghasilan atau income yang tersedia bagi pemilik perusahaan atas modal yang mereka investasikan di dalam perusahaan.Committee on terminologydalam Harahap (2001:220) mendefinisikan "profitabilitas adalah jumlah yang berasal dari pengurangan harga pokok produksi, biaya lain dan kerugian dari penghasilan atau penghasilan operasi". Sedangkan menurut APB Statement dalam Harahap (2001:226) mengartikan "profitabilitas adalah kelebihan (defisit) penghasilan diatas biaya selama 
satu periode akuntansi". Menurut Simamora (2000:528) "Profitabilitas merupakan ukuran pokok keseluruhan keberhasilan perusahaan". Dari pengertian diatas dapat disimpulkan bahwa profitabilitas adalah Penghasilan yang diinginkan oleh perusahaan dalam menjual produknya pada periode akuntansi tertentu.

\section{Penerapan Strategi Pemasaran yang Tepat.}

Untuk meningkatkan pendapatan perusahaan, pihak manajemen harus dapat menentukan strategi pemasaran yang tepat. Strategi pemasaran yang diterapkan manajemen akan memberikan pengaruh terhadap tingkat penghasilan perusahaan. Pemasaran merupakan salah satu kegiatan pokok yang dilakukan oleh pengusaha dalam usahanya untuk mempertahankan kelangsungan usahanya untuk mendapatkan laba dan keuntungan. Berhasil tidaknya pencapaian tujuan bisnis tergantung pada keahlian pihak perusahaan dalam mengkombinasikan fungsi-fungsi pemasarannya agar organisasi dapat berjalan lancar. Menurut Lupiyoadi (2001:32) "Pemasaran adalah salah satu kebutuhan manusia yang diarahkan untuk memenuhi kebutuhan dan keinginan melalui proses pertukaran yang bertujuan untuk membuat penjualan-penjualan yang berlebihan dan mengetahui serta memehami konsumen dengan baik hingga produk atau layanan cocok dengan baik konsumen tersebut dan laku dengan sendirinya".

Pemasaran pada dasarnya menarik pelanggan agar membeli suatu produk dengan proses usaha, baik dengan permintaan yang nyata maupun yang masih potensial akan barang-barang dan jasa diformulasikan, diusahakan dan disediakan oleh penjualan. Proses itu mencakup upaya semua bidang fungsi penjualan yang bekerja sama untuk menghasilkan jasa-jasa atau produk yang harganya tepat, waktunya pasti, tempatnya jelas sehingga dapat memenuhi permintaan pasar mencapai tingkat keuntungan pemasaran itu. Pemasaran yang efektif menghendaki perencanaan yang baik dari menentukan konsep tentang kualitas, desain, kemasan, harga, cara penyampaian produk kepada konsumen pada waktu dan jumlah yang tetap loyal terhadap produk yang diciptakan. Pemasaran merupakan salah satu fungsi utama diantara fungsifungsi lainnya yang dalam suatu perusahaan seperti administrasi pembukuan, pembelanjaan, produk dan personalia. Bahkan ada yang berpendapat bahwa pemasaran adalah merupakan fungsi-fungsi yang ada dalam perusahaan. Strategi pemasaran merupakan suatu manajemen yang disusun untuk mempercepat pemecahan persoalan pemasaran dan membuat keputusan-keputusan yang bersifat strategis. Setiap fungsi manajemen memberikan kontribusi tertentu pada saat penyusunan strategi pada level yang berbeda. Pemasaran merupakan fungsi yang memiliki kontak paling besar dengan lingkungan eksternal, padahal perusahaan hanya memiliki kendali yang terbatas terhadap lingkungan eksternal. Oleh karena itu pemasaran memainkan peranan penting dalam pengembangan strategi.

Menurut Tjiptono (2000:6) dalam peranan strategisnya, pemasaran mencakup setiap usaha untuk mencapai kesesuaian antara perusahaan dengan lingkungannya dalam rangka mencari pemecahan atas masalah penentuan dua pertimbangan pokok, yaitu: "a. Bisnis ada yang digeluti perusahaan pada saat ini dan jenis bisnis apa yang dapat dimasuki di masa mendatang. b. Bagaimana bisnis yang telah dipilih tersebut dapat dijalankan dengan sukses dalam lingkungan yang kompetitif atas dasar perspektif produk, harga promosi dan distribusi (bauran pemasaran) untuk melayani pasar sasaran". Dalam konteks penyusunan strategi, pemasaran memiliki 2 (dua) dimensi, yaitu dimensi saat ini dan dimensi yang akan datang. Dimensi saat ini berkaitan dengan hubungan yang telah ada antara perusahaan dengan lingkungannya. Sedangkan dimensi masa yang akan datang mencakup hubungan dimasa yang akan datang yang diharapkan akan dapat terjalin dan program tindakan yang diperlukan untuk mencapai tujuan tersebut. Menurut Kotler (2004:92) "Strategi pemasaran terdiri dari prinsip-prinsip dasar yang mendasari manajemen untuk mencapai tujuan bisnis dan pemasarannya dalam sebuah pasar sasaran, strategi pemasaran mengandung keputusan dasar tentang pemasaran, bauran pemasaran, dan alokasi pemasaran".

Dari pengertian di atas struktur manajemen pemasaran strategis menggambarkan masukan yang digunakan perusahaan untuk mengidentifikasi dan memilih strategi. Masukan tersebut diperoleh melalui analisis lingkungan internal dan lingkungan eksternal. Kekuatankekuatan lingkungan makro yang utama meliputi :demografi, teknologi, politik, hukum dan sosial budaya yang mempengaruhi bisnis. Disamping itu perlu selalu memonitor pelaku-pelaku lingkungan mikro yang utama yaitu : pelanggan pesaing, saluran distribusi, pemasok, pendatang baru dan produk pengganti yang akan mempengaruhi kemampuan perusahaan untuk memperoleh laba dipasar sasaran. Dalam Strategi pemasaran terdiri atas lima elemen-elemen yang saling berkait. Kelima elemen tersebut menurut Tjiptono (2000:6-7) adalah: Pemilihan pasar, yaitu memilih pasar yang akan dilayani. Keputusan ini didasarkan pada faktorfaktor berikut ini. Persepsi terhadap fungsi produk dan pengelompokan teknologi yang dapat diproteksi dan didominasi; Keterbatasan sumbar daya internal yang mendorong perlunya pemusatan (fokus) yang sempit ; Pengalaman kumulatif yang didasarkan pada trial-aud-error di dalam menanggapi peluang 
dari akses terhadap sumber daya langka atau pasar yang terproteksi.

Pemilihan pasar dimulai dengan melakukan segmentasi pasar dan kemudian memilih pasar sasaran yang paling memungkinkan untuk dilayani oleh perusahaan.Perencanaan produk, meliputi spesifik yang terjual, pembentukan lini produk dan desain penawaran individual pada masing-masing lini. Produk itu sendiri menawarkan manfaat total yang dapat diperoleh pelanggan dengan melakukan pembelian. Manfaat tersebut meliputi produk itu sendiri, nama merek produk, ketersediaan produk, jaminan atau garansi, jasa reparasi dan bantuan teknis yang disediakan penjual, serta hubungan personal yang mungkin terbentuk diantara pembeli dan penjual; Penetapan harga, yaitu menentukan harga yang dapat mencerminkan nilai kuantitatif dari produk kepada pelanggan; Sistem distribusi, yaitu saluran perdagangan grosir dan eceran yang dilalui produk hingga mencapai konsumen akhir yang membeli dan menggunakannya; Komunikasi pemasaran (promosi), yang meliputi periklanan, personal selling, promosi penjualan, direct marketing dan publick relations.

Dalam merumuskan strategi pemasaran dibutuhkan pendekatan-pendekatan analistis. Menurut Tjiptono (2000:7) pendekatan strategi pemasaran suatu perusahaan untuk menanggapi setiap perubahan kondisi pasar dan faktor biaya tergantung pada analisis terhadap faktor-faktor berikut ini: Faktor lingkungan, Analisis terhadap faktor lingkungan seperti pertumbuhan populasi dan peraturan pemerintah sangat penting untuk mengetahui pangaruh yang ditimbulkannya pada bisnis perusahaan. Selain itu faktor-faktor seperti perkembangan teknologi, tingkat inflasi dan gaya hidup juga tidak boleh diabaikan. Hal-hal tersebut merupakan faktor lingkungan yang harus dipertimbangkan sesuai dengan produk dan pasar perusahaan; Faktor pasar. Setiap perusahaan perlu selalu memperhatikan dan mempertimbangkan faktor-faktor seperti ukuran pasar, tingkat pertumbuhan, tahap perkembangan, trend dalam sistem distribusi, pola perilaku pembeli, permintaan musiman, segmen pasar yang ada saat ini atau yang dapat dikembangkan lagi, dan peluang-peluang yang belum terpenuhi. Faktor persaingan. Dalam kaitannya dengan persaingan, setiap perusahaan perlu memahami siapa pesaingnya, bagaimana posisi produk/pasar pesaing tersebut, apa strategi mereka, kekuatan dan kelemahan pesaing, struktur biaya pesaing, dan kapaistas produksi pesaing; Faktor analisis kemampuan internal. Setiap perusahaan perlu menilai kekuatan dan kelemahan dibandingkan para pesaingnya. Penilaian tersebut dapat didasarkan pada faktor-faktor seperti tekhnologi, sumber daya finansial, kemampuan pemanufakturan, kekuatan pemasaran dan basis pelanggan yang dimiliki; Faktor perilaku konsumen. Perilaku konsumen perlu dipantau dan dianalisis karena hal ini sangat bermanfaat bagi pengembangan produk, desain produk, penetapan harga, pemilihan saluran distribusi dan penentuan strategi promosi. Analisis perilaku konsumen dapat dilakukan dengan penelitian (riset pasar), baik melalui observasi maupun metode survay; Faktor analisis ekonomi. Dalam analisis ekonomi, perusahaan dapat memperkirakan pengaruh setiap peluang pemasaran terhadap kemungkinan mendapatkan laba. Analisis ekonomi terdiri atas analisis terhadap komitmen yang diperlukan, analisis $\mathrm{BEP}$ (break even point), penilaian resiko/laba, dan analisis faktor ekonomi pesaing.

Menurut Kurtz (2008:35) strategi pemasaran adalah "sebuah keseluruhan, program perusahaan untuk menentukan target pasar dan memuaskan konsumen dengan membangun kombinasi elemen dari bauran pemasaran; produk, distribusi, promosi, dan harga". Menurut Kotler (2008:36) "dalam upaya mendapatkan kepuasan konsumen di tengah persaingan, perusahaan harus mengerti terlebih dahulu apa kebutuhan dan keinginan konsumennya". Sebuah perusahaan menyadari bahwa perusahaan tidak dapat memenuhi keinginan konsumen yang berbedabeda. Perusahaan menyiapkan strategi pemasaran dengan memilih segmen konsumen terbaik yang dapat menciptakan keuntungan yang sebesarbesarnya.

Sebagai dasar untuk mencapai tujuan sebuah perusahaan, yaitu mendapatkan profit, pemasar harus merancang strategi yang benarbenar tepat dengan menggunakan bauran pemasaran (marketing mix). Bauran pemasaran menurut Kotler (2004:120) yaitu: Product (Produk) Produk merupakan perpaduan benda atau jasa dari perusahaan yang dibutuhkan dan dapat memuaskan target pasar. Produk ini ditawarkan kepada konsumen dalam wujud tangible maupun intangible. Produk dalam jasa perhotelan adalah desain dasarnya, termasuk ukuran dan fasilitas hotel, suasana dan lingkungan yang diciptakan sedemikian rupa, pelayanan, branding dan citra yang merupakan sintesis dari semua elemen produk. Price (Harga) Harga merupakan sejumlah uang yang harus dibayarkan oleh konsumen untuk mendapatkan produk dari sebuah perusahaan. Harga dapat dijadikan sebagai dasar penawaran yang ditetapkan sedemikian rupa sehingga menarik minat pasar. Place (Tempat distribusi)Tempat atau lokasi suatu produk dapat dijangkau konsumen sehingga terjadi transaksi jual-beli. Strategi pemilihan tempat terdiri dari aksesibiltas transportasi, pergudangan, pengaturan persediaan, dan cara pemesanan bagi konsumen. Dalam dunia perhotelan, unsur tempat ini mencakup lokasi dan keadaan hotel tersebut dan juga kemudahannya mendapat informasi dari agen atau biro perjalanan wisata. Promotion (Promosi).Suatu metode komunikasi informasi yang ditujukan kepada target 
pasar tentang barang atau jasa yang ada pada in the right place at the right time. Kegiatan promosi dilakukan untuk mepengaruhi target pasar untuk membeli produk yang ditawarkan. Kegiatannya antara lain iklan, personal selling, promosi penjualan, dan public relation.

Komponen marketing mixtersebut saling mempengaruhi satu sama lain sehingga semuanya penting sebagai satu kesatuan yang dikombinasikan perusahaan untuk mencapai tujuan yang telah ditetapkan. Pemasaran tidak terbatas pada proses penjualan barang, jasa atau ide saja. Tetapi pemasaran menggunakan berbagai strategi dalam menyampaikan nilai dan kegunaan kepada konsumen. Menurut Tjiptono (2008:5) "pemasaran bertujuan untuk menarik pembeli dalam mengkonsumsi produk yang ditawarkan. Oleh karena itu pemasaran memainkan peranan penting dalam pengembangkan strategi". Assauri (2007:168) mengemukakan pendapat "strategi pemasaran adalah serangkaian tujuan dan sasaran, kebijakan dan aturan yang memberi arah kepada usaha-usaha pemasaran perusahaan dari waktuke waktu, pada masing-masing tingkatan dan acuan serta alokasinya, terutama sebagai tanggapan perusahaan dalam menghadapi lingkungan dan keadaan persaingan yang selalu berubah. Strategi pemasaran memegang peranan penting dalam rencana pemasaran suatu perusahaan untuk mencapai tujuan pemasarannya. Dengan demikian, strategi pemasaran harus dapat memberi gambaran yang jelas dan terarah tentang apa yang dilakukan perusahaan dalam menggunakan setiap kesempatan atau peluang pada beberapa pasar sasaran. Dalam hal ini dibutuhkan dunia bagian yangsangat penting dan saling berkaitan, untuk mencapai keberhasilan kegiatan pemasaran yang dilakukan oleh suatu perusahaan, yaitu sasaran pasar yang dituju (target market) dan acuan pemasaran yang dijalankan (marketing mix) untuk sasaran pasar tersebut.

Menurut Assuari (2007:187) 'Dalam rencana strategi pemasaran perusahaan terdapat landasan strategi di dalam pemasaran perusahaan, yang dikenal dengan strategi produk-pasar (product-market strategy), yaitu produk yang akan dipasarkan perusahaan dan pasaryang dilayani perusahaan". Dari landasan strategi ini menurut Assuari (2007:190) dapat ditetapkan alternatif strategi pemasaran, yaitu: Strategi Penetrasi Pasar. Strategi ini bertujuan untuk meningkatkan posisi perusahaan yang dihubungkan dengan produk dan pasar yang sedang dilayani perusahaan sekarang ini. Strategi Pengembangan Produk. Strategi ini menekankan pada peningkatan (mutu dan lain-lain) dari produk yang dipasarkan perusahaan pada saat ini dengan sasaran pasar yang dituju (target market) yang sama. Strategi Perluasan/Pengembangan Pasar. Strategi ini ditujukan untuk mendapatkan pasar atau kelompok konsumen yang baru melalui perbaikan produk yang ada. Strategi Penggantian Produk. Strategi ini menekankan pada penggantian produk yang ada dengan produk yang lebih baik secara terusmenerus. Strategi Segmentasi Pasar dengan Diferensiasi Produk. Strategi ini ditujukan untuk menarik perhatian konsumen baru dengan memperbesar pilihan produk yang telah ada. Strategi Perluasan Product-Line.Strategi ini digunakan untuk menghadapi perkembangan teknologi dengan memperluas product-lineyang dapat ditawarkan kepada konsumen. Strategi Diversifikasi Produk. Strategi ini bertujuan untuk menarik konsumen baru dengan menambah jenisjenis produk baru baik yang berkaitan dengan teknologi dan cara pemasaran produk yang telah ada maupun yang tidak berkaitan. Strategi Integrasi. Strategi ini bertujuan untuk meningkatkan rentabilitas (profitability), efisiensi, dan pengendalian melalui penggabungan atau integrasi dengan perusahaan yang ada hubungannya dengan proses produksi yang dijalankan selama ini.

\section{Pengelolaan Aset yang Baik}

Setiap manajemen perusahaan memerlukan suatu alat ukur untuk mengukur kinerja perusahaannya. Salah satu alat ukur untuk mengetahui baik atau tidaknya performa perusahaan dapat dilihat dari kinerja manajemen dalam mengelola aset perusahaan. Pada kenyataannya banyak perusahaan yang memiliki aset yang kuat tetapi masih mengalami masalah dalam pencapaian kemampulabaan, hal ini disebabkan oleh buruknya kinerja manajemen dalam melakukan pengelolaan asetnya. Manajemen aset adalah suatu potensi yang dimiliki oleh organisasi atau perseorangan untuk mencapai visi misi dan atau tujuan khususnya. Aset perusahaan terdiri dari aktiva lancar dan aktiva tetap. Aktiva lancar atau current assetadalah jenis aktivayang dapat digunakan dalam jangka waktu dekat, biasanya satu tahun. Contoh aktiva lancar antara lain adalah kas, piutang, investasijangka pendek, persediaan, dan bebandibayar di muka. Sedangkan aktiva tetap atau fixed aset adalah aktiva berwujudyang memiliki umur lebih dari satu tahun dan tidak mudah diubah menjadi kas. Jenis aktiva tidak lancarini biasanya dibeli untuk digunakan untuk operasi dan tidak dimaksudkan untuk dijual kembali. Contoh aktiva tetap antara lain adalah properti, bangunan, pabrik, alat-alat produksi, mesin, kendaraan bermotor, dan lain-lain. Manajemen aset dilakukan dengan cara mengatur aset perusahaan dengan standar baku 
perusahaan dalam setiap pos nya agar tidak terjadi penumpukan aset dalam setiap pos, serta memproduktifkan aset yang ada sehingga tidak ada aset perusahaan yang menganggur. Pengelolaan aset yang baik diharapkan perusahaan dapat membayar kewajiban jangka pendeknya saat jatuh tempo atau menjamin setiap kewajibannya saat akan ditagih dengan aktiva yang dimiliki, pada kondisi seperti ini perusahaan dikatakan likuid. Sebaliknya jika pengelolaan aset dilakukan kurang baik maka peluang perusahaan untuk dapat membayar semua kewajiban jangka pendeknya saat jatuh tempo menjadi kecil atau perusahaan tidak dapat menjamin semua kewajibannya dengan aktiva yang dimiliki, pada kondisi seperti ini perusahaan dikatakan ilikuid. Perusahaan yang dikatakan likuid memiliki peluang lebih besar dalam meningkatkan kemampulabaannya, namun perusahaan yang dikatakan ilikuid memiliki peluang yang kecil dalam meningkatkan kemampulabaannya.

Untuk mengetahui kinerja keuangan perusahaan ada 3 aspek yang perlu dilihat yaitulikuiditas, solvabilitas dan kemampu-labaan atau sering juga disebut dengan profitabilitas, tetapi dalam penelitian ini penulis hanya membahas dari segi kemampulabaan atau profitabilitas usaha. Para investor dan kreditur sangat berkepentingan dalam mengevaluasi kemampuan perusahaan dalam menghasilkan laba saat ini maupun di masa mendatang. Berapa pun besarnya likuiditas maupun solvabilitas perusahaan jika tidak mampu menggunakan modalnya secara efesien didalam memperoleh laba maka perusahaan tersebut akan mengalami kesulitan keuangan. Begitu juga halnya bagi pemilik perusahaan bahwa yang menjadi daya tarik utama bagi mereka adalah kemampulabaan. Menurut Harahap (2006:304) "kemampulabaan menggambarkan kemampuan perusahaan mendapatkan laba melalui semua kemampuan dan sumber yang ada dalam periode tertentu, seperti kegiatan penjualan, kas, modal, jumlah karyawan, jumlah cabang. Dalam hal ini kemampulabaan berarti hasil yang diperoleh melalui usaha manajemen terhadap dana yang diinvestasikan pemilik perusahaan".

Banyak cara atau teknik dalam menganalisis manajemen aset salah satunya dengan menggunakan laporan keuangan dengan memakai alat bantu analisis common size dan analisis rasio. Dengan menggunakan analisis rasio dapat membandingkan perusahaan yang satu dengan lainnya sehingga kita dapat melihat perkembangan perusahaan secara periodik atau times series. Selain analisis rasio teknik lainnya yaitu analisis common size. Analisis ini digunakan untuk mengukur struktur keuangan perusahaan dengan cara mengkonversi laporan keuangan kedalam laporan bentuk awam dengan menggunakan denominator persentase.

Manajemen aset merupakan suatu teori baru dalam ilmu properti yang muncul akibat adanya kenyataan bahwa suatu wilayah khususnya Indonesia yang memiliki kekayaan sumber daya, baik sumber daya alam, manusia maupun infrastruktur. Berikut ini akan dijelaskan mengenai pengertian manajemen dan aset. Menurut Nawawi (2003:121) "Manajemen merupakan serangkaian proses yang terdiri atas perencanaan (planning), pengorganisasian (organizing), pelaksanaan (actuating), pengawasan (controlling) dan penganggaran (budgeting)". Menurut Siregar (2004:175) pengertian aset adalah "barang (thing)atau sesuatu barang (anything)yang mempunyai nilai ekonomi (economic value), nilai komersial (commercial value)atau nilai tukar (exchange value) yang dimiliki oleh badan usaha, instansi atau individu. Ada dua jenis aset yaitu aset berwujud (tangible) dan aset tidak berwujud (intangible)". Menurut Hariyono (2007) "Pengelolaan Aset adalah kegiatan mengelolasuatu barang yangdimiliki mulai dari perencanaan, pengadaan, operasi, danpemeliharaan serta penghapusan".

\section{Sumber Daya Manusia dalam Perusahaan}

Karyawan sebagai sumberdaya utama perusahaan dituntut untuk memberikan pelayanan terbaik kepada konsumen dan memberikan kinerja yang optimal sehingga konsumen merasa terlayani dengan baik dan merasa puas. Karena jika konsumen merasa tidak puas dapat melakukan komplain yang dapat merusak citra perusahaan. Hal ini menunujukkan bahwa sumber daya manusia sangat berpengaruh terhadap kesuksesan perusahaan dalam pencapaian tujuannya. Sumber daya manusia mempunyai fungsi mengelola input yang dimiliki perusahaan secara maksimal untuk mendapatkan hasil yang diharapkan oleh perusahaan. Oleh karena itu perusahaan sebisa mungkin membuat para karyawan dapat melaksanakan pekerjaannya dalam keadaan yang tenang dan nyaman, tanpa ada ketegangan dan kecemasan yang dirasakan. Kondisi ini bukan hanya menyangkut keadaan fisik saja, melainkan juga berhubungan dengan hubungan sosial dengan orang lain dan suasana psikologis di tempat kerja. Dengan suasana kerja atau lingkungan kerja yang menyenangkan akan membuat karyawan bekerja secara optimal. Sumber Daya Manusia merupakan faktor yang sangat penting untuk setiap usaha, begitu pula untuk pemerintahan agar dapat menjalankan fungsinya sebenar-benarnya. Banyak defenisi yang dapat digunakan untuk 
mendefenisikan sumber daya manusia. Menurut Susilo (2002:3) "sumber daya manusia adalah pilar penyangga utama sekaligus penggerak roda organisasi dalam usaha mewujudkan visi dan misi dan tujuannya".

Menurut Mathis dan Jackson (2002:4) "Sumber daya manusia harus didefinisikan bukan dengan apa yang sumber daya manusia lakukan, tetapi apa yang sumber daya manusia hasilkan". Maka dari itu, Sumber Daya Manusia merupakan faktor yang penting bagi setiap usaha. Menurut Tambunan (2003:15) "Sumber daya manusia yang berkualitas akan menentukan kejayaan atau kegagalan dalam persaingan". Menurut Mathis dan Jackson (2002:29) yaitu: Nilai sumber daya manusia adalah jumlah nilai dari sumber daya manusia pada sebuah organisasiyang dapat juga disebut sebagai modal intelektual yang terdiri dari orang-orang dalam organisasi, kemampuan yang mereka miliki, dan menggunakannya dalam pekerjaan mereka. Sehingga bagian terpenting dari peningkatan nilai sumber daya manusia adalah dengan mendayagunakan semua bakat-bakat orang-orang yang ada dalam organisasi dan mengambil yang terbaik dari populasi yang bervariasi di luar organisasi. Disebabkan perubahan kependudukan tenaga kerja, manajemen sumber daya manusia harus memaksimalkan kapabilitas sumber daya manusia yang bervariasi. Ditambahkan, praktisi sumber daya manusia haruslah orang-orang yang meyakinkan semua tenaga kerja tanpa melihat latar belakang mereka, menyediakan kesempatan untuk mengembangkan kapabilitas mereka.

Sumber Daya Manusia (SDM) merupakan salah satu elemen terpenting yang akan memutar roda perusahan terus berjalan. Meskipun ini tidak berhubungan langsung dengan keuangan atau pendapatan perusahaan, namun secara tidak langsung dapat berimbas pada kinerja perusahaan. Hal ini karena pada dasarnya sumberdaya manusialah yang bergerak mengelola perusahaan. Sumber daya manusia yang bermutu semakin dibutuhkan setiap perusahan untuk mencapai sasaran perusahaan. Semakin baik kualitas sumber daya manusia dalam sebuah perusahaan maka daya saing perusahaan tersebut akan semakin baik. Perusahaan harus melakukan program training untuk meningkatkan kehandalan karyawan, kecerdasan dan integritasnya untuk perusahaan.

Perusahaan wajib memberikan komitmen terhadap karyawannya untuk mendapatkan kesempatan mewujudkan tujuan pribadi. Komitmen ini yang tertulis pada aturan dan prosedur dan pemilihan manjer yang baik, memperjelas visi dan misi perusahaan. Selain itu juga untuk membentuk tradisi perusahaan. Perusahaan juga wajib mendorong karyawannya untuk terus melakukan pengembangan dan mengembangkan diri sebagaimana hak seorang karyawan. Pemanfaatan sumber daya manusia haruslah berlangsung dengan baik dengan perencanaan sumberdaya yangbaik pula. Dimulai dari pengaturan kembali dan penempatan SDM pada posisi yang tepat. Menempatkan sesuai dengan kemampuan dan pengalaman yang dimilikinya. Sehingga pemberian kontribusi karyawan dapat berlangsung maksimal. Hal ini menjadi salah satu tuntutan penting yang harus dikuasai oleh seorang manajer SDM, apalagi dengan perkembangan zaman dan pergerakan ekonomi, arus informasi dan perkembangan iptek semakin pesat membuat kualitas SDM semakin dibutuhkan dengan kualitas terbaik.

\section{METODE PENELITIAN}

Jenis penelitian adalah sesuatu yang dapat diartikan sebagai mengatur latar (Setting) penelitian agar memperoleh data yang tepat (Vallid) sesuai dengan karakteristik variabel dan tujuan penelitian. Menurut Campbell dan Stanley dalam Moleong (2000:236) "Jenis penelitian (Research Design) adalah tahap perlakuan sebelum dan sesudah eksperimen". Sedangkan menurut Chrism dalam Moleong (2000:236) "Memandang sebagai tahap-tahap pelaksanaan data". lokasi penelitian pada CV. Mambae Group Sintang dengan alamat Jalan Y.C. Oevang Oeray Sintang.

\section{HASIL PENELITIAN DAN PEMBAHASAN}

\section{Penerapan Strategi Pemasaran yang Tepat}

Strategi pemasaran adalah alat fundamental yang direncanakan untuk mencapai perusahaan dengan mengembangkan keunggulan bersaing yang berkesinambungan melalui pasar yang dimasuki dan program pemasaran yang digunakan untuk melayani pasar sasaran tersebut. Strategi pemasaran adalah logika pemasaran, dan berdasarkan itu, unit bisnis diharapkan untuk mencapai sasaran-sasaran pemasarannya. Strategi pemasaran terdiri dari pengambilan keputusan tentang biaya pemasaran dari perusahaan, bauran pemasaran, dan alokasi pemasaran. Strategi pemasaran dapat dinyatakan sebagai dasar tindakan yang mengarah pada kegiatan atau usaha pemasaran, dari suatu perusahaan, dalam kondisi persaingan dan lingkungan yang selalu berubah agar dapat mencapai tujuan yang diharapkan.

Berdasarkan hasil penelitian diperoleh data dan informasi mengenai pekerjaan sipil yang pernah dikerjakan oleh CV. Mambae Sintang sejak tahun 2014-2016, sebagaimana tergambar dalam tabel berikut ini: 
Tabel 1. Pengalaman Pengerjaan Proyek Pemerintah Tahun 2014

\begin{tabular}{|c|l|l|r|}
\hline No. & \multicolumn{1}{|c|}{ Lingkup Pekerjaan } & \multicolumn{1}{|c|}{ Lokasi } & Nilai kontrak (Rp.) \\
\hline 1. & Jalan usaha tani & Kabupaten Sintang & 293.598 .000 \\
2. & Pembangunan Embung & Kabupaten Sintang & 54.455 .000 \\
3. & Pembuatan DAM Parit & Kabupaten Sintang & 99.346 .000 \\
4. & Jaringan Irigasi Tingkat & Kabupaten Sintang & 192.417 .000 \\
& Usaha Tani (JITUT) & & \\
5. & Jaringan Irigasi Tingkat & Kabupaten Sintang & 192.884 .000 \\
\hline
\end{tabular}

Sumber: Dokumen CV. Mambae Sintang, 2018.

Perusahaan cukup besar memperoleh proyek pemerintah yang bersumber dari APBD Kabupaten Sintang Tahun Anggaran 2014. Selain itu CV. Mambae juga mengerjakan pekerjaan dari swasta pada tahun 2014 yaitu pembangunan rumah tinggal (ekterior dan interior) senilai Rp.1.000.000.000,- (satu milyar).

Tabel 2. Pengalaman Pengerjaan Proyek Pemerintah Tahun 2015

\begin{tabular}{|c|l|l|r|}
\hline No. & \multicolumn{1}{|c|}{ Lingkup Pekerjaan } & \multicolumn{1}{|c|}{ Lokasi } & Nilai kontrak (Rp.) \\
\hline 1. & Penimbunan Gg. Pakis & Kabupaten Sintang & $90.504 .000,-$ \\
2. & Pembangunan Kolam Bak Terpal & Kabupaten Sintang & $29.550 .000,-$ \\
3. & Pembangunan Kolam Bak Terpal & Kabupaten Sintang & $39.200 .000,-$ \\
4. & Pembangunan Kolam Bak Terpal & Kabupaten Sintang & $39.400 .000,-$ \\
5. & Pembangunan Keramba Jaring & & \\
& Apung & Kabupaten Sintang & $48.404 .000,-$ \\
6. & Pembangunan Kolam Bak Semen & Kabupaten Sintang & $59.400 .000,-$ \\
7. & Pembangunan Keramba Jaring & & \\
& Apung & Kabupaten Sintang & $60.600 .000,-$ \\
8. & DAM Parit & Kabupaten Sintang & $89.510 .000,-$ \\
9. & DAM Parit & Kabupaten Sintang & $89.530 .000,-$ \\
10. & Jaringan Irigasi Tingkat Usaha & Kabupaten Sintang & $179.490 .000,-$ \\
& Tani (JITUT) & & \\
11. & Jaringan Irigasi Tingkat Usaha & Kabupaten Sintang & $179.510 .000,-$ \\
& Tani (JITUT)
\end{tabular}

Sumber: Dokumen CV. Mambae Sintang, 2018.

Selain pekerjaan pemerintah tersebut, perusahaan pada tahun 2015 tidak ada mengerjakan pekerjaan pihak swasta. Selanjutnya pekerjaan yang dikerjakan CV. Mambae pada tahun 2016 sebagaimana tergambar pada tabel berikut ini:

Tabel 3. Pengalaman Pengerjaan Proyek Pemerintah Tahun 2016

\begin{tabular}{|c|l|l|r|}
\hline No. & \multicolumn{1}{|c|}{ Lingkup Pekerjaan } & \multicolumn{1}{c|}{ Lokasi } & Nilai kontrak (Rp.) \\
\hline 1. & $\begin{array}{l}\text { Pembangunan Pagar } \\
\text { Pusekesmas Kebong } \\
2 .\end{array}$ & $\begin{array}{l}\text { Pengadaan Electric } \\
\text { Generating Set RSUD } \\
\text { Rehab Rumah Dinas } \\
\text { Kandepag Sintang }\end{array}$ & Kabupaten Sintang \\
Kabupaten Sintang & Kabupaten Sintang & $135.000 .000,-$ \\
\hline
\end{tabular}

Sumber: Dokumen CV. Mambae Sintang, 2018. 
Pada tahun 2016 ini perusahaan CV. Mambae Sintang memperoleh pekerjaan dari pihak swasta yang cukup besar yaitu pembangunan Hotel dan Office CU Keling Kumang Sintang senilai Rp.5.000.000.000,- (lima milyar). Pekerjaan pembangunan hotel dan kantor CU Keling Kumang ini merupakan pekerjaan besar yang dikerjakan oleh CV. Mambae Sintang dan hasilnya cukup memuaskan, serta horel yang ada menjadi salah satu hotel yang sangat menarik penampilannya. CV. Mambae Sintang sudah cukup berhasil meningkatkan pendapatannya sebagai perusahaan yang bergerak di bidang jasa kontraktor, sedangkan untuk jasa interior masih belum maksimal hal ini dapat disebabkan karena masyarakat kota Sintang dalam membangun rumah belum banyak yang menggunakan jasa arsitek interior untuk merancang bangunan rumah tinggalnya.

Perusahaan sudah mampu menerapkan segmentasi pasar yang sesuai dengan kemampuan perusahaan. Sebagaimana teori bahwa segmentasi pasar (Market Segmentation), adalah tindakan membagi pasar menjadi kelompok pembeli dengan kebutuhan, karakteristik, atau perilaku berbeda yang mungkin memerlukan produk atau bauran pemasaran terpisah. Perusahaan CV. Mambae cukup mampu menetapkan target pasar perusahaan baik pada pihak pemerintah maupun pihak swasta. Persaingan yang cukup besar di sektor jasa kontraktor mengakibatkan perusahaan harus mampu memberikan penawaran yang sebaik-baiknya dengan mengutamakan kualitas pekerjaan yang sesuai dengan keinginan pemberi pekerjaan. Dengan demikian tentunya CV. Mambae akan mampu bersaing dengan perusahaan-perusahaan sejenis.

\section{Pengelolaan Aset yang Baik}

Asset yang dimiliki perusahaan belumlah banyak terutama yang berbentuk materiil, sedangkan untuk asset immaterial perusahaan memiliki sumber daya manusia yang menguasai bidang pekerjaannya sesuai dengan pendidikan dan pengalaman yang dimiliki oleh para karyawan. Beberapa asset perusahaan dalam bentuk materiil dapat dilihat pada tabel berikut ini:

Tabel 4.. Daftar Peralatan CV. Mambae Sintang.

\begin{tabular}{|c|l|c|c|}
\hline No. & \multicolumn{1}{|c|}{ Jenis Peralatan } & Jumlah & Keterangan \\
\hline 1. & Kantor dan Studio & 1 unit & Kondisi Baik \\
2. & Meja Kerja & 4 buah & Kondisi Baik \\
3. & Computer & 1 unit & Kondisi Baik \\
4. & Laptop & 2 unit & Kondisi Baik \\
5. & Printer & 1 unit & Kondisi Baik \\
6. & UPS & 1 unit & Kondisi Baik \\
7. & Kamera & 2 buah & Kondisi Baik \\
8. & Jam Dinding & 1 buah & Kondisi Baik \\
9. & Kipas Angin & 2 buah & Kondisi Baik \\
10. & Waterpass & 1 unit & Kondisi Baik \\
11. & Meteran & 2 buah & Kondisi Baik \\
12. & Kompas & 2 buah & Kondisi Baik \\
13. & Kendaraan roda dua & 2 unit & Kondisi Baik \\
14. & Mesin molen & 1 unit & Kondisi Baik \\
15. & Kompresor & 1 unit & Kondisi Baik \\
\hline
\end{tabular}

Sumber: Dokumen CV. Mambae Sintang, 2018.

Perusahaan sudah memiliki peralatan yang dapat mendukung pekerjaannya, walaupun masih sangat terbatas namun sudah dapat mengatasi pekerjaan jasa yang ditawarkan oleh perusahaan. Perusahaan juga sudah membangun jaringan dengan pihak ketiga yang memiliki peralatan penunjang pekerjaan sipil yang cukup banyak saat ini. Asset utama dari perusahaan keberadaan sumber daya manusia yang memiliki keahlian dan pengalaman di bidang pekerjaan jasa arsitektur dan konstruksi, ini tentu saja merupakan modal yang sangat berharga. Aset dalam akuntansi adalah sumber daya atau kekayaan yang dimiliki oleh suatu entitas. Di mana, setiap perusahaan pasti memiliki sebuah aset, baik yang berwujud seperti tanah, bangunan, perlengkapan, atau pun yang tak berwujud seperti saham, hak cipta, dan merek. Aset merupakan bagian terpenting dari sebuah perusahaan yang harus dikelola dengan baik untuk mendapatkan manfaat bagi perusahaan, sekaligus mendorong tercapainya tujuan perusahaan. Dengan manajemen aset, perusahaan dapat menjaga nilai aset yang dimiliki tetap tinggi, memiliki usia yang lebih panjang, serta menghindari kerusakan 
terhadap aset yang bisa menyebabkan turunnya nilai jual. Untuk menjaga nilai aset, perusahaan harus menyediakan biaya operasional yang memadai sehingga menghasilkan output yang tinggi dan sesuai dengan tujuan perusahaan.

\section{Sumber Daya Manusia dalam Perusahaan.}

Sumber Daya Manusia yang ada atau karyawan berjumlah 5 (lima) orang dalam menjalankan kegiatan operasional perusahaan. Kelima orang karyawan yang ada ini merupakan tenaga ahli di bidangnya masing-masing. Karyawan perusahaan yang ada merupakan karyawan tetap perusahaan dengan sistem penggajian melalui bagi hasil pekerjaan yang diperoleh.

CV. Mambae Sintang dipimpin oleh seorang yang memiliki kemampuan di bidang arsitektur sesuai dengan bidang usaha perusahaan, selain itu perusahaan juga didukung oleh karyawan yang juga memiliki kemampuan sesuai dengan pendidikannya seperti sarjana desain interior, sarjana teknik informatika yang sangat menunjang kegiatan operasional perusahaan. Sumber daya manusia adalah modal utama dalam menjalankan perusahaan, tanpa didukung oleh kemampuan karyawan yang memiliki kemampuan di bidangnya maka perusahaan tidak dapat berjalan secara efektif dan efisien. CV. Mambae Sintang sudah memiliki sumber daya manusia yang cukup baik dan sesuai dengan bidang tugas perusahaan, sehingga perusahaan dapat berjalan dengan baik dan dapat meningkatkan profitabilitas perusahaan.

Sumberdaya merupakan aset perusahaan yang paling unik, paling rentan, paling murni dan sukar diperkirakan. Setiap karyawan memiliki seperangkat latar belakang yang berbeda, yang akan mempengaruhi harapan masing- masing dan pada gilirannya akan mempengaruhi dinamika hubungan antara manusia dan organisasi perusahaan. Harapan individual atau kelompok karyawan boleh jadi sama, tidak sama atau sama sekali bertentangan dengan harapan perusahaan. Interaksi dua harapan dan tujuan itu beserta negoisasinya mempengaruhi kontrak psikologis yang mewujud dalam budaya organisasi.

Pada dasarnya suatu organisasi bukan saja mengharapkan karyawan mau dan mampu bekerja secara giat, tetapi bagaimana memiliki motivasi yang tinggi dari setiap karyawan guna meningkatkan kinerjanya. Sumber daya manusia merupakan faktor yang dominan dalam mencapai tujuan organisasi perlu mendapat perhatian secara khusus. Pimpinan unit kerja atau instansi memiliki kewajiban untuk selalu memotivasi pegawai agar meningkatkan kinerjanya, dengan demikian kerjasama dan saling memahami tugas dan fungsi dari setiap unit kerja sangat diperlukan. Sebuah perusahaan yang sedang mengalami perkembangan usaha diharapkan akan mampu menciptakan produktivitas yang tinggi, karena tingkat produktivitas perusahaan itu sendiri yang akan menentukan tingkat keberhasilan suatu perusahaan. Kontribusi terbesar dalam usaha meningkatkan produktivitas perusahaan adalah dengan kemampuan sumber daya manusia atau tenaga kerjanya. Dengan demikian perusahaan perlu meningkatkan produktivitas kerja karyawan semaksimal mungkin, agar profitabilitas perusahaan juga dapat meningkat.

\section{KESIMPULAN DAN SARAN}

Perusahaan sudah menerapkan strategi yang tepat sehingga perusahaan mampu memperoleh pekerjaan kontruksi baik pekerjaan dari pemerintah maupun dari pihak swasta. Perusahaan sudah memiliki asset yang dapat mendukung operasional perusahaan baik asset dalam bentuk materiil maupun immaterial.Perusahaan sudah memiliki sumber daya manusia yang mumpuni sesuai dengan pendidikan dan pengalamannya, sehingga menjadi salah satu faktor penunjang keberhasilan perusahaan.Perusahaan diharapkan terus meningkatkan performancenya sehingga dapat meningkatkan kepercayaan pemberi pekerjaan baik pemerintah maupun swasta. Secara bertahap perusahaan agar dapat meningkatkan asset-aset perusahaan, sehingga dapat menambah kepercayaan pemberi kerja.Terus mempertahankan keberadaan sumber daya manusia yang ahli di bidangnya masing-masing, dengan cara terus meningkatkan penghasilannya.

\section{DAFTAR PUSTAKA}

Assauri, S.2007.Manajemen Pemasaran. Jakarta: Rajawali Pers.

Harahap, S.2001.Sistem Pengawasan Manajemen. Jakarta: Penerbit Quantum.

Hariyono. 2007.Modul Diklat Teknis Manajemen Aset Daerah. Jakarta.

Kotler. $2008 \quad$.Manajemen

Pemasaran.Jakarta:Macanan Jaya

Cemerlang.

Kotler, P. and Armstrong, G.2008.Prinsip-prinsip Pemasaran. Edisi. 12. Jilid 1. Jakarta: Erlangga

Kurtz, D. L. 2008.Pengantar Bisnis Kontemporer, buku 1. Jakarta: Salemba Empat.

Lupiyoadi, R. 2006.Manajemen pemasaran Jasa Teori dan Praktik, edisi pertama, Jakarta: Salemba Empat.

Mathis, dan Jackson, 2002. Manajemen Sumber Daya Manusia. Edisi pertama. Cetakan Pertama. Yogyakarta : Salemba Empat

Michelle, dan Megawati. 2005. Memprediksi Tingkat Pengembalian Investasi Melalui Rasio Profitabilitas, Likuiditas, 
danLeverage (Studi pada Perusahaan Manufaktur yang Listingdi BEI Perioda Pengamatan Tahun 2001-2004). Tesis. Program Pascasarjana UniversitasAirlangga Surabaya.

Moleong, L.J. 2006. Metodologi Penelitian Kuantitatif. Bandung: PT. Remaja Rosdakarya.

Nawawi, H.2003.Manajemen Sumber Daya Manusia Untuk Bisnis yang. Komptitif, Gadjah Mada University Press, Yogyakarta.
Nawawi, H. 2007. Metode Penelitian Bidang Sosial. Yogyakarta: Gajah Mada University Press.

Prastowo, D. 2008. Analisis Laporan Keuangan, Edisi Kedua Sekolah Tinggi Ilmu ManajemenYKPN.

Siregar, Doli.D. 2004. Manajemen Aset. Jakarta: Satyatama Graha Tara.

Susilo. M.2002.Manajemen Sumber Daya Manusia. Edisi Kedelapan. Yogyakarta: BPFE.

Tjiptono, F.2008.Strategi Pemasaran, Edisi 3. Yogyakarta: ANDI. 